\title{
COVID-19, infordemic, and evidence-based dentistry
}

Deuk-Sang Ma

\author{
The President of the Korean Academy of Preventive Dentistry and Oral Health
}

Infordemic, a portmanteau of "information" and "epidemic", refers to the rapid spread of excess information, including false and misleading information, during a disease outbreak.

We are amid an unprecedented COVID-19 era. Ever since the virus was first reported in China in November 2019, it has spread globally, leading to a prolonged pandemic, with numerous confirmed cases and deaths. Scientists have been diligently conducting studies to find means to prevent or treat the infection. Preventive vaccination is one of the major methods that can end the pandemic. Vaccines have been developed based on scientific evidence accumulated until now, and are being used to vaccinate people. Although evidence-based information on vaccination announced by official organizations should be trusted, numerous undocumented pieces of information generated by the media and individuals, taking advantage of people's anxiety, have led to an infordemic. While news such as vaccination inducing dementia and causing mutations in the human genome is clearly false from a scientific perspective, such information is blinding people, leading to hesitations in receiving vaccinations.

A good example of the infordemic negatively affecting national health promotion can be found in the field of dental health, where a water fluoridation project was suspended. Despite its benefit, based on scientific evidence, to prevent dental caries, the project was not implemented widely because of false information and a lack of understanding. Similar to how vaccines are used to prevent infectious diseases, finding and trusting evidence-based information while collecting dental health-related information is necessary to avoid infordemics that adversely affect the promotion of dental health. Moreover, scientists should provide evidencebased diagnoses and information by continuously researching to support the evidence. In this context, the Journal of Korean Academy of Oral Health will continue to serve as a platform for evidence-based dentistry that helps combat infordemics.

June 2021 


\section{코로나 19, 인포데믹(infordemic) 그리고 근거기반치의학(evidence-based dentisty)}

마득상

대한예방치과 · 구강보건학회 회장

인포데믹은 영어의 information과 epidemic의 합성어로 정보의 과잉, 홍수 속에서 제대로 된 정보를 찾기 어렵게 되는 상태로 잘못된 정보 가 감염병처럼 사람들에게 확산되어 퍼지는 것을 의미한다.

우리는 이제껏 경험해 본적이 없는 코로나 시대에 살고 있다. 2019년 11월 중국에서 최초 보고된 이후 전 세계로 감염이 확산되어 매우 많은 감염자와 사망자를 기록하며 장기화되고 있고, 과학자들은 이를 예방하거나 치료할 수 있는 방법을 찾는 연구에 전력을 기울이고 있다. 예방백신 은 코로나 사태를 종식시킬 수 있는 주요한 수단 중 하나이며, 지금까지 연구된 과학적 근거를 바탕으로 백신을 개발하여 접종을 시행하고 있다. 백신접종과 관련된 정보는 공식 기관을 통해서 발표되는 근거에 기반한 정보를 신뢰하여야 함에도 불구하고, 많은 언론과 개인 들이 사람들의 불 안감에 편승해 쏟아내는 확실하지 않은 정보가 인포데믹 현상을 일으키고 있다. 백신 접종이 치매를 유발하고 사람의 유전자를 변형시킨다는 것과 같은 정보 들은 조금만 과학적으로 접근해 보면 명백한 가짜뉴스 임에도 사람들이 이에 현혹되어 백신접종을 주저하게 만드는 원인이 되고 있다.

구강보건분야에서 인포데믹에 의해 국민건강증진에 악영향을 미친 대표적인 사례는 수돗물불소농도조정사업(water fluoridation)의 중단에 서 찾아볼 수 있다. 과학적 근거에 기반한 치아우식예방사업 임에도 잘못된 정보와 이해 부족으로 활성화되지 못한 사업이다. 전염병이 발생하면 백신을 통해 예방하듯 구강건증진에 악영향을 미치는 인포데믹을 예방하려면 개인은 구강건강관련 정보를 수집하는 과정에서 근거에 기반한 정 보를 찾고 신뢰하는 자세를 가져야 하고, 과학자는 근거를 뒷받침할 연구를 꾸준히 수행하여 근거에 기반한 진료와 정보를 제공하하여야 할 것이 다. 이러한 측면에서 대한구강보건학회지는 인포데믹을 바로 잡는 근거기반치의학의 플랫폼 역할을 계속해 나갈 것이다.

2021. 6. 